\title{
Margaret McCartney: General practice is a long game
}

\author{
Margaret McCartney general practitioner \\ Glasgow
}

At the end of another long and difficult day, it's easy to lose all sense of the joy of working as a GP. It's still there, under a pile of paperwork maybe, but it's still there.

I'm thinking about the baby born after many years of trying, when you exchange smiles with the parents, who know too well the years of tears and infertility.

I'm thinking about the bereaved husband, and the wife who came to talk to you about her fears around how he'd manage after her death. His wife understood that you'd still be around after she died and that you'd still be offering care to her husband.

I'm thinking about the person you haven't seen for a few years, but who returned to the practice to see you because you helped with her depression before.

The relationships that general practice allows us to form with patients can last decades

General practice is joy in small things, and small things are big things. It's there when you say hello to someone who's at the practice to see not you but the nurse. But you know these patients, their mothers, their sisters. You know that they're at the practice to have blood tests to monitor the cancer you diagnosed last year. You both know this.

The relationships that general practice allows us to form with patients can last decades. They weave between families and overlap across illnesses, presentations, treatment choices, and even death. They make it easier to handle uncertainty, to talk about dying, to think about mortality, to grieve, to make rational choices, and to feel joy.

If you rip the longitudinal care out of general practice, it's just a set of interactions to be monitored by tick box targets or analysed as data on "activity in primary care." Take the relationships with people out of general practice and you have an unsustainable future.

General practice is a risk sink: we are the depository of much uncertainty, which allows an affordable NHS to exist. But it can only work when it's supported by trust between patients and doctors. We make judgments about whom we trust, and those judgments are stronger and better when they're formed over time.

If we ensure that long term relationships are the default priority, we'll be closer to getting back to the joy we all need in our working lives.

Competing interests: See www.bmj.com/about-bmj/freelancecontributors/margaret-mccartney.

Provenance and peer review: Commissioned; not externally peer reviewed.

Follow Margaret on Twitter, @mgtmccartney

Published by the BMJ Publishing Group Limited. For permission to use (where not already granted under a licence) please go to http://group.bmj.com/group/rights-licensing/ permissions 